DOI https://doi.org/10.30525/978-9934-588-80-8-2.3

\title{
ОСОБЛИВОСТІ ЗАСТОСУВАННЯ МЕТОДИК КОНТРОЛЮ ЗНАНЬ ПРИ ДИСТАНЦІЙНІЙ ФОРМІ НАВЧАННЯ
}

\author{
Водоп'ян Н. I. \\ аспірант
}

Інститут інформаційних технологій $і$ засобів навчання

Національної академії педагогічних наук Украӥни, заступник директора комунального закладу освіти "Дніпровський лічей інформаційних технологій при Дніпровському начіональному університеті імені Олеся Гончара» Дніпровської міської ради м. Дніпро, Україна

В сучасних умовах пріоритетним для закладів загальної середньої освіти $€$ питання дистанційного навчання. Відповідно до Положення про дистанційне навчання, затвердженого наказом МОН України № 466 від 25.042013 року, технології дистанційного навчання у загальноосвітніх закладах зорієнтовані насамперед на учнів 3 особливими освітніми потребами, обдарованих дітей та молодь, які спроможні самостійно опанувати навчальний матеріал; осіб, які проживають у географічно віддалених і важкодоступних до закладів освіти населених пунктах або за кордоном. Виходячи 3 епідеміологічної ситуації в Україні, яка склалась в березні-червні 2020 року, в закладів освіти не було іншого варіанту, крім застосування технологій дистанційного навчання для всіх учнів при проведенні занять під час довготривалого карантину. Дистанційні ресурси, які за звичайних умов використовувались лише епізодично, як допоміжні, в екстреному порядку були задіяні для організації повноцінного навчального процесу в закладах освіти.

Сучасні інформаційні технології дають змогу задовольнити запити суспільства в якісній освіті. Але в Україні розвиток систем дистанційної освіти перебуває на початковій стадії впровадження. Використання дистанційної освіти здійснюється переважно в складі звичайної освіти $[1$, с. 6].

Дистанційну освіту визнано одним 3 ключових напрямків основних культурно-освітніх програм ЮНЕСКО, протягом останніх десятиліть вона стала глобальним явищем освітньої та інформаційної культури. Технології дистанційного навчання дозволяють отримувати повноцінну освіту тим, хто з різних причин відірваний від освітніх центрів, за 
станом здоров'я, особливостей способу життя, в силу територіальної віддаленості. Класичні уроки, лекції, семінари, практичні заняття, тести, електронні підручники, контрольні завдання та консультації викладачів у будь-який час доступні для тих, хто навчається дистанційно. Вітчизняний і зарубіжний досвід теорії та практики дистанційного навчання підтверджує актуальність і новизну даного напрямку розвитку освіти, наближає нас до розуміння сутності дистанційного навчання, яке $є$ одним із способів отримання освіти.

Одним 3 основних завдань сучасної освіти є розвиток самоосвітніх навичок, уміння навчатись протягом життя, будувати власну освітню траєкторію та успішно реалізовувати знання на практиці. Важливу роль у плануванні та реалізації індивідуальної освітньої траєкторії відіграють процеси інформатизації освіти, що спонукають до зміни методів і засобів навчання, пошуку нових форм презентації навчального матеріалу, якісного контролю знань, виконання практичної частини освітніх програм.

Крім того, саме дистанційна освіта значно розширює можливості та коло освітніх послуг за допомогою використання системи безперервної освіти, гнучких графіків проведення занять у синхронному та асинхронному режимах. Основною особливістю гнучких режимів навчання $\epsilon$ те, що вони не так жорстко регламентують часові та просторові рамки проведення занять і спілкування між викладачами та учнями. Очевидно, що реалізація зазначених вище принципів сьогодні можлива тільки в тому випадку, якщо традиційне навчання буде доповнено дистанційним, заснованим на сучасних віртуальних комунікаціях. Розроблені та успішно використовуються різні системи дистанційного навчання (кейсова, мережева, телекомунікаційна та їх варіанти). Виникає потреба в безперервному отриманні та наданні інформації. Ця особливість виникає завдяки стрімкому розвитку науково-технічного прогресу, коли протягом короткого відрізку часу одна інформаційна технологія змінюе іншу, з'являються нові пристрої, змінюються принципи роботи та природно виникає потреба обміну інформацією за допомогою нових інформаційних технологій. Це призводить до необхідності безперервного навчання протягом усього життя людини. Безперервність навчання разом 3 відкритістю і доступністю лежить в основі концепції освіти в інформаційному суспільстві $[1$, с. 5].

Безумовно, дистанційне навчання має будуватися відповідно до дидактичних принципів сучасної педагогіки: об'єктивності, науковості, зв'язку теорії з практикою, послідовності, систематичності, доступності при необхідній мірі труднощів, наочності та різноманітності методів, 
свідомості і активності учнів, міцності засвоєння знань, умінь i навичок.

Оцінювання навчальних досягнень учнів є невід'ємною складовою освітнього процесу. У ході планування уроків і навчальних тем одним 3 аспектів, який заслуговує на увагу, є питання, як контролювати й забезпечувати прогрес учнів у навчанні, як оцінити результати учнівських досягнень.

В системі дистанційного навчання контроль набуває особливого значення, тому що взаємодія викладача i студентів проходить опосередковано, в умовах інформаційного середовища ВНЗ. У зв'язку з цим необхідно використовувати такі методи і форми перевірочних заходів, які, з одного боку, компенсували б відсутність особистого контакту з викладачем, а з іншого, - представили б процедуру контролю як сучасний технологічний процес, привабливий для його учасників [2, c. 2].

У статті 17 Закону України «Про повну загальну середню освіту» говориться, що кожен учень має право на справедливе, неупереджене, об'єктивне, незалежне, недискримінаційне та доброчесне оцінювання результатів його навчання незалежно від виду та форми здобуття ним освіти.

Основними функціями оцінювання навчальних досягнень учнів $є$ : контролююча, навчальна, стимулювально-мотиваційна, виховна, діагностико-коригувальна. Ці орієнтири покладено в основу чотирьох рівнів навчальних досягнень учнів: початкового, середнього, достатнього, високого. Критерії оцінювання навчальних досягнень реалізуються в нормах оцінок, які встановлюють чітке співвідношення між вимогами до знань, умінь і навичок, які оцінюються, та показником оцінки в балах. Основною метою поточного та формувального оцінювання учнів в умовах дистанційного навчання $є$ не перевірка $\mathrm{i}$ контроль, а забезпечення зворотного зв'язку вчителя з учнями. Тому в організації щоденного освітнього процесу варто надавати пріоритет оцінюванню, яке передбачає надання учням підтримки, коригування засобів та методів навчання у випадку виявлення їх неефективності [3, c. 143].

Існує кілька варіантів підходу до контролю знань учнів під час дистанційного навчання. Перший 3 них - це контроль активності учня. Дана система застосовується в тому випадку, коли потрібно, щоб учень відвідав певну кількість навчальних занять, практичних або лабораторних робіт, брав участь в проектній діяльності. Однак, недолік такого підходу очевидний: відвідування занять не дає гарантії якості освіти. 
Другий підхід до оцінювання заснований на виявленні якості знань учня, застосуванні на практиці отриманих навичок. При його використанні спостерігається зміщення акценту до педагогіки компетентності. Однак, цей підхід тягне за собою проблеми при застосуванні його в дистанційній освіті. Якщо при перевірці теоретичних знань можна використати тестування в дистанційному режимі, то перевірка компетентностей - практичних умінь стикається 3 проблемою моделювання процесів. Для такої перевірки необхідні різноманітні тренажери, віртуальні лабораторні комплекси, стенди.

Третій підхід - виконання учнями навчальних проектів, де $\epsilon$ можливість як показати свої теоретичні знання так і комплексно продемонструвати свої вміння. Особливістю цього підходу є створення нестандартних завдань, які не мають готових відповідей, що дає можливість учневі самостійно підібрати і перевірити різні варіанти, продемонструвавши свої знання і вміння.

Оцінювання результатів навчальної діяльності може здійснюватися у синхронному або асинхронному режимі. Синхронний режим дозволяє забезпечити більш об'єктивне оцінювання, проте вимагає відповідного технічного забезпечення у вчителя та всіх учнів. Залишається ризик технічних збоїв під час виконання окремими учнями завдання, тому слід застосовувати індивідуальний підхід та передбачити можливість повторного виконання тесту (контрольної, самостійної роботи тощо).

Асинхронний режим є більш гнучким у застосуванні, оскільки учні можуть виконувати завдання у зручний час, проте менш об'єктивним. Для зменшення ризиків необ'єктивного оцінювання рекомендовано налаштувати опцію проходження тесту один раз та обмежити час на виконання завдання, встановити термін для здачі тесту (контрольної, практичної або самостійної роботи тощо), повідомляти результати (у разі неавтоматизованої перевірки робіт) індивідуально після здачі робіт всіма учнями. За необхідності учитель може провести додаткове усне опитування учнів за допомогою одного із засобів телефонного або відеозв'язку.

Вірно підібрані методики контролю знань допомагають учням i викладачам змістовно брати участь у програмах дистанційної освіти, забезпечують якість дистанційного навчання.

\section{Література:}

1. Відкрита та дистанційна освіта: від теорії до практики: зб. матер. III Всеукр. електронної наук.-практ. конф., 27 вересня 2018 р. [ред. кол.: Л. Л. Ляхоцька (голов. ред.), С. П. Касьян, С. В. Антощук, 
Т. І. Сябрук]. - К. : ДВНЗ «Університет менеджменту освіти» НАПН України, 2018. - 166 с.

2. Курицина Г.В. Формы и методы контроля качества дистанционного обучения студентов ВУЗа // Международный журнал экспериментального образования. - 2014. - № 8-3. - С. 17-21

3. Водоп'ян Н.І. Організація оцінювання навчальних досягнень учнів в умовах дистанційного навчання засобами Microsoft Forms: Використання системи комп'ютерного моделювання в умовах дистанційного навчання: збірник матеріалів за заг. ред. С.Г. Литвинової, О.М. Соколюк. Київ: ФОП Ямчинський О.В. 2020. 195 с.

DOI https://doi.org/10.30525/978-9934-588-80-8-2.4

\title{
ЗАКОНОМІРНОСТІ І ПРИНЦИПИ КОНЦЕПЦІЇ РОЗВИТКУ ПРОФЕСІЙНО-ПЕДАГОГІЧНОЇ КОМПЕТЕНТНОСТІ ВИКЛАДАЧІВ ТЕХНІЧНИХ ЗАКЛАДІВ ВИЩОЇ ОСВІТИ
}

\author{
Горохівська Т. М. \\ кандидат педагогічних наук, \\ доиент кафедри педагогіки та інновачійної освіти \\ Національний університет «Львівська політехніка» \\ м. Львів, Україна
}

Як прояв сучасної філософії освіти методологічну основу української освіти становить гуманістична парадигма, метою якої $є$ виховання духовно багатої, національно свідомої особистості, суб'єкта повноцінної професійної діяльності. Через це в умовах реформування вищої вітчизняної школи помітної актуальності набуває проблема розвитку професійно-педагогічної компетентності викладачів технічних ЗВО. Реалізація цієї проблеми передбачає обгрунтування концепції розвитку професійно-педагогічної компетентності викладачів технічних ЗВО, важливими складовими компонентами якої є закономірності і принципи, розгляду яких і присвячена ця робота.

Важливою характеристикою будь-якого процесу, який відбувається в суспільстві (у тому числі і педагогічного) є закономірна логіка. Саме вона визначає напрям руху процесу, що залежить від вищих орієнтирів, на досягнення яких спрямовані усі зміни, які відбуваються у межах цього процесу. Закономірна логіка обумовлює закономірний невипадковий характер змін, що відбуваються в умовах процесу, 